\title{
PENGARUH MODEL PEMBELAJARAN DAN KESADARAN METAKOGNISI TERHADAP HASIL BELAJAR PESERTA DIDIK KELAS X SMA ISLAM KOTA TERNATE (Pokok Bahasan Ikatan Kimia)
}

\author{
Desma Sonyinga \\ Email:desma_sonyinga@yahoo.com
}

\begin{abstract}
ABSTRAK
Penelitian ini merupakan penelitian eksperimen semu yang bertujuan untuk mengetahui pengaruh model pembelajaran dan kesadaran metakognisi terhadap hasil belajar peserta didik kelas X SMA Islam Kota Ternate pada pokok bahasan ikatan kimia. Penelitian ini menggunakan rancangan Desain penelitian faktorial 2x2. Sampel terdiri atas dua kelas yang dipilih dengan random sampling teknik acak kelas. Kelas X IPA 1 sebagai kelas eksperimen 1 dibelajarkan dengan model pembelajaran inkuiri terbimbing dan kelas X IPA 2 sebagai kelas eksperimen 2 dibelajarkan dengan model pembelajaran berbasis masalah. Instrument penelitian yang digunakan yaitu angket inventori kesadaran metakognisi dan tes hasil belajar. Data yang diperoleh dianalisis secara inferensial dan deskriptif. Hasil analisis inferensial diperoleh bahwa: (1) model pembelajaran berpengaruh terhadap hasil belajar peserta didik dengan nilai signifikansi yang diperoleh yaitu $0,01<0,05$. (2) kesadaran metakognisi berpengaruh terhadap hasil belajar peserta didik dengan nilai signifikansi yang diperoleh yaitu $0,008<0,05$. (3) terdapat interaksi model pembelajaran dengan kesadaran metakognisi, terlihat pada nilai signifikansi yang diperoleh yaitu $0,014<0,05$. Selanjutnya hasil analisis deskriftif diperoleh bahwa: (1) rata-rata nilai hasil belajar peserta didik yang menggunakan model pembelajaran inkuiri terbimbing hasilnya lebih tinggi dibandingkan dengan model pembelajaran berbasis masalah. (2) rata-rata nilai hasil belajar peserta didik dengan kesadaran metakognisi tinggi, lebih tinggi dibandingkan dengan rata-rata nilai hasil belajar dengan kesadaran metakognisi rendah, dan (3) terjadi interaksi interaksi antara model pembelajaran dan kesadaran metakognisi dalam mempengaruhi hasil belajar peserta didik kelas X IPA SMA Islam Kota Ternate. Jadi, ada pengaruh antara model pembelajaran dan kesadaran metakognisi terhadap hasil belajar peserta didik kelas X SMA Islam Kota Ternate pada pokok bahasan ikatan kimia.
\end{abstract}

Kata Kunci: Inkuiri Terbimbing, Pembelajaran Berbasis Masalah, Metakognisi, Hasil Belajar.

\begin{abstract}
The study is quasi experiment which aims at examining the influence of learning model and metacognition awareness on learning autocomes of grade $\mathrm{X}$ at SMA Islam in Ternate city on chemistry Bond subject. The study employed $2 \times 2$ factorial research desaign. Samples consisted of two classes selected by employing random sampling technique and obtained grade X IPA 1 as the experiment class 1 taught by using guided inquiry learning model and grade X IPA 2 as experiment class 2 taught by using problem-based learning model. The research instruments used questionnaire of metacognition awareness inventory and learning result test. Data obtained were analyzed inferentially and descriptively. The results of inferential analysis reveal that (1) the learning model gives influence on learning outcomes with significant score of $0.01<0.05$, (2) The metacognition awareness give influence on learning outcomes with significant score $0.008<0.05$, (3) there is interaction of learning model and metacognition awareness, proved by the significant score $0.014<0.05$. Then, the results of descriptive analysis indicate that (1) the mean score of learning outcomes taught
\end{abstract}


using guided inquiry learning model is higher than problem-based learning model, (2) the mean score of learning outcomes with high metacognition awareness is higher than the mean score of learning outcomes with low metacognition awareness, (3) there is interaction between learning model and metacognition awareness in influencing learning outcomes of grade X IPA at SMA Islam in Ternate city. Therefore, there is influence between learning model and metacognition awareness on learning outcomes of grade $\mathrm{X}$ at SMA Islam in Ternate city on Chemistry Bond subject.

Keyword: guided inquiry, problem-based learning, metacognition, learning outcomes.

\section{PENDAHULUAN}

Pendidikan adalah usaha sadar dan terencana untuk mewujudkan suasana belajar dan proses pembelajaran agar peserta didik secara aktif mengembangkan potensi dirinya untuk memiliki kekuatan spiritual keagamaan, pengendalian diri, kepribadian, kecerdasan, akhlak mulia, serta ketrampilan yang diperlukan dirinya, masyarakat, bangsa dan negara. Tujuan Pendidikan nasional adalah mencerdaskan kehidupan bangsa dan mengembangkan manusia seuutuhnya, yaitu manusia yang beriman dan bertaqwa terhadap Tuhan Yang Maha Esa dan berbudi pekerti luhur, memiliki pengetahuan dan ketrampilan, kesehatan jasmani dan rohani, kepribadian yang mantap dan mandiri serta rasa tanggung jawab kemasyarakatan dan kebangsaan. (UU No.20 tahun 2003 pasal 1 ayat 1 tentang system pendidikan nasional)..

Masalah pendidikan merupakan masalah yang paling penting dalam kehidupan sehari-hari, baik dalam kehidupan keluarga maupun dalam kehidupan masyarakat. Jika semua unsur pendidikan mempunyai tanggung jawab terhadap peningkatan mutu pendidikan maka tidak akan sulit untuk meningkatkan mutu pendidikan.

Fakta bahwa di SMA Islam Kota Ternate menunjukkan bahwa hasil belajar kimia peserta didik masih perlu dikembangkan Hal ini dapat menyebabkan peserta didik sulit dalam memahami konsep-konsep kimia yang abstrak, yang berakibat pada rendahnya hasil belajar kimia.
Sehubungan dengan hal itu perlu diperhatikan guru dalam pembelajaran kimia adalah seorang guru harus dapat mendesain pembelajaran sehingga peserta didik dapat lebih aktif mengikuti proses pembelajaran, misalnya dengan melakukan interaksi berupa tanya jawab atau pemberian resitasi selama proses pembelajaran berlangsung.

Guru sebagai tenaga pendidik harus bisa menerapkan model pembelajaran yang mampu melibatkan peserta didik secara aktif dalam proses pembelajaran kimia di kelas. Guru harus mengubah pola pikir peserta didik dan mengajukan pertanyaanpertanyaan yang membutuhkan analisis tinggi dan penyelesaiannya. Guru juga harus mengaktifkan kesadaran metakognisi peserta didik dalam proses pembelajaran. Belajar dengan instruksi metakognisi berarti bahwa guru akan memikirkan bagaimana proses dalam mengaktifkan kesadaran metakognisi peserta didik. Kesadaran metakognisi dapat dijadikan sebagai proses seseorang dalam belajar. Kesadaran metakognisi mempengaruhi seseorang dalam menyerap dan mengolah informasi sehingga akan mempengaruhi peserta didik dalam memperbaiki hasil belajarnya. Kesadaran metakognisi sangat diperlukan untuk kesuksesan belajar. Sehubungan dengan itu, kesadaran metakognisi peserta didik mampu mengelola kecakapan kognitif dan mampu melihat kelemahannya sehingga dapat dilakukan perbaikan pada pembelajaran selanjutnya. Kesadaran metakognisi memungkinkan peserta didik untuk melakukan perencanaan, mengikuti 
perkembangan dan memantau proses belajarnya (Wibowo, 2007).

Kadir (2009) menyatakan bahwa Pembelajaran yang berorientasi pada pengembangan ketrampilan berpikir dapat menjadi alternatif untuk perbaikan kemampuan berpikir peserta didik dalam memahami konsep kimia. Salah satu upaya untuk membangun kemampuan berpikir peserta didik dapat dilakukan dengan pengembangan aspek metakognisinya. Kemampuan metakokognisi mempunyai indikator yang mencerminkan tingkat ketercapaiannya yaitu ketika peserta didik mampu berpikir dengan mengoptimalkan kemampuan berpikir yang dimiliki, mengidentifikasi strategi belajar yang baik dan secara sadar mengarahkan strategi belajarnya. (Haryani 2012) menyatakan bahwa pengembangan metakognisi ditujukan agar peserta didik dapat menjadi pemikir-pemikir kritis yang selalu berpikir dalam menerapkan suatu motivasi internal. Sementara menurut Livingston (Haryani, 2012) metakognisi memiliki peran penting dalam keberhasilan belajar, oleh karena itu penting mempelajari aktivitas dan pengembangannya untuk menentukan bagaimana peserta didik dapat diajar menerapkan sumber-sumber pengetahuan mereka dengan lebih baik melalui kontrol meta-kognisinya.

Menghadapi kenyataan tersebut, diperlukan suatu upaya untuk mengaktifkan kesadaran metakognisi peserta didik agar nantinya berdampak pada peningkatan hasil belajar peserta didik. Salah satu caranya adalah dengan pemilihan model pembelajaran yang tepat sehingga dapat mendorong siswa mengembangkan kemampuan metakognisinya. Salah satu model pembelajaran yang dapat mempengaruhi kemampuan berpikir peserta didik yaitu model pembelajaran inkuiri dan psikomotor melalui penghayatan secara internal akan masalah yang dihadapi (Suryanti,2010). terbimbing yang dapat mendorong peserta didik berpikir dan bekerja atas inisiatif. Kebiasaan kegiatan ini dapat merangsang dan meningkatkan berpikir kritis pada peserta didik. Peserta didik dapat menemukan jawaban atas pertanyaan yang dirumuskan. Penerapan model pembelajaran inkuiri terbimbing dapat meningkatkan antusias peserta didik dalam pelaksanaan kegiatan pembelajaran (Handayani, 2012). Pembelajaran inkuiri terbimbing merupakan pembelajaran kelompok di mana peserta didik diberi kesempatan untuk berpikir mandiri dan saling membantu dengan teman yang lain. Penerapan inkuiri terbimbing dapat meningkatkan kualitas pemahaman konsep peserta didik dan mampu tertanam karakter pada peserta didik.

Model pembelajaran lainnya yang juga memperhatikan kemampuan metakognisi serta aktivitas penemuan pada peserta didik adalah pembelajaran berbasis masalah. Pembelajaran berbasis masalah adalah kegiatan penemuan dimana pembelajaran dimulai dengan pemberian masalah, peserta didik secara berkelompok aktif merumuskan masalah dan mengidentifikasi kesenjangan pengetahuan mereka, mempelajari dan mencari sendiri materi yang terkait dengan masalah dan melaporkan solusi dari masalah serta pendidik lebih banyak memfasilitasi (Amir, 2009). Pembelajaran berbasis masalah (PBM) merupakan salah satu pembelajaran yang didasarkan kepada psikologi kognitif yang berangkat dari asumsi bahwa belajar adalah proses perubahan tingkah laku berkat adanya pengalaman. Melalui proses ini peserta didik akan berkembang secara utuh, artinya perkembangan peserta didik tidak hanya terjadi pada aspek kognitif tetapi juga aspek

afektif

Hasil penelitian yang dilakukan oleh (Tamsyani, 2016) terjadi interaksi antara model pembelajaran dengan kesadaran metakognisi dalam mempengaruhi hasil 
belajar peserta didik. Penelitian yang dilakukan oleh (Linanti et al, 2017) menunjukkan bahwa terdapat pengaruh yang signifikan antara model pembelajaran inkuiri terbimbing terhadap metakognisi peserta didik kelas XI yang ditunjukkan dengan nilai probabilitas dan rata-rata respon peserta didik termasuk dalam kategori baik.

Demikian model pembelajaran inkuiri terbimbing dan pembelajaran berbasis masalah berpengaruh terhadap hasil belajar kognitif peserta didik yang dapat beriringan dengan peningkatan kemampuan metakognisi peserta didik. Oleh sebab itu peneliti tertarik atas pengaruh-pengaruh tersebut melalui prosedural ilmiah dengan mengangkat judul "Pengaruh Model Pembelajaran dan kesadaran metakognisi terhadap hasil belajar peserta didik Kelas X SMA Islam Kota Ternate pada pokok bahasan ikatan kimia".

\section{METODE PENELITIAN}

Jenis penelitian yang digunakan pada penelitian ini adalah penelitian quasi experiment (eksperimen semu). Desain yang digunakan dalam penelitian ini adalah desain faktorial $2 \times 2$. Desain ini menggunakan variabel bebas, model pembelajaran dibagi dua yaitu model pembelajan inkuiri terbimbing dan model pembelajaran berbasis masalah dan kesadaran metakognisi dibagi menjadi dua kategori yaitu kesadaran metakognisi tinggi dan kesadaran metakognisi rendah.

Waktu penelitian dilakukan dari bulan September hingga oktober 2018. Tempat penelitian dilakukan pada kelas $\mathrm{X}$ SMA Islam Kota Ternate.

Populasi dalam penelitian ini yaitu seluruh peserta didik kelas XI IPA SMA Islam Kota Ternate tahun ajaran 2018/2019 yang terdiri dari 4 Kelas yang berjumlah 120 peserta didik. Pengambilan sampel dalam penelitian ini menggunakan teknik random sampling class sehingga sampel yang digunakan dalam penelitian ini adalah 2 kelas eksperimen yaitu kelas IPA 1 dan Kelas IPA 2.

Model pembelajaran (A) merupakan variabel bebas manipulatif yang terdiri atas dua bagian yaitu: model pembelajaran inkuiri terbimbing (A1) dan model pembelajaran berbasis masalah (A2). kesadaran metakognitif (B) merupakan variabel bebas atributif yang terdiri atas dua bagian yaitu: kesadaran metakognisi tinggi (B1) dan kesadaran metakognisi rendah (B2). Variabel terikat dalam penelitian ini adalah hasil belajar peserta didik kelas $\mathrm{X}$ SMA Islam Kota Ternate tahun ajaran 2017/2018 pada materi ikatan kimia.

Penelitian ini dilaksanakan Satu kali pertemuan untuk pemberian inventori berupa angket kesadaran metakognisi untuk masing-masing kelas eksperimen. Empat kali pertemuan proses belajar untuk setiap penerapan model pembelajaran pada masing-masing kelas eksperimen. Satu kali pertemuan pemberian tes hasil belajar untuk masing-masing kelas eksperimen.

Untuk melaksanakan model pembelajaran inkuiri terbimbing dan model pembelajaran berbasis masalah, maka dibuat instrumen penelitian yang terdiri dari angket inventori kesadaran metakognisi, RPP, LKPD dan tes hasil belajar yang telah divalidasi isi oleh pihak yang berkompeten (validator).

Teknik pengumpulan data dalam penelitian ini adalah dengan pemberian tes akhir hasil belajar. Soal tes hasil belajar yang digunakan untuk masing-masing kelas eksperimen adalah sama. Instrumen tes yang digunakan mencakup indikator pada pokok bahasan ikatan kimia. Tes kesadaran metakognisi menggunakan pembagian angket MAI (Schraw \& Dennison, 1986) yang terdiri dari 52 item untuk mendapatkan data tentang kesadaran metakognisi peserta didik. Kuisioner ini pertanyaannya masing masing 4 item jawaban yaitu sangat benar (SB), benar (B), 
tidak benar (TB) dan sangat tidak benar (STB).

Analisis data untuk Pembobotan yang dilakukan berdasarkan arah pernyataan yang ditentukan berdasarkan skala liker model skala empat (Ghazali, 2006). Selanjutnya skor total dan rata-rata skor total dan ratarata skor total dihitung untuk setiap item inventori kesadaran metakognisi. Skor kesadaran metakognisi peserta didik dapat diubah kedalam bentuk nilai dengan menggunakan rumus:

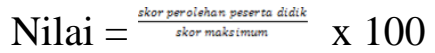

Nilai skor akhir yang diperoleh dikonversi ke dalam pedoman konversi pengkategorian (Blakey \& spance, 2008) yang tersaji pada Tabel 1.

Tabel 1 pedoman pengkategorian kesadaran metakognisi

\begin{tabular}{c|c}
\hline Nilai skor & Kategori \\
\hline $0-71$ & Rendah \\
$72-100$ & Tinggi \\
\hline
\end{tabular}

Analisis statistik deskriptif digunakan untuk mendeskripsikan secara umum hasil belajar peserta didik pada materi pokok ikatan kimia untuk setiap kelas eksperimen, yang terdiri dari nilai rata-rata (mean), median, modus, standar deviasi, skor tertinggi dan skor terendah. Analisis data penelitian ini diolah dengan menggunakan SPSS. Untuk mengetahui nilai hasil belajar peserta didik dapat menggunakan rumus sebagai berikut. Kriteria penilaian menggunakan rumus arikunto (2006), yaitu:

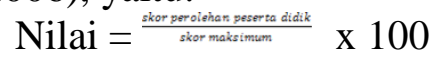

Data perolehan hasil belajar peserta didik selanjutnya dikelompokkan berdasarkan ketuntasan hasil belajar, Untuk mengetahui ketuntasan hasil belajar peserta didik dibandingkan dengan kriteria ketuntasan minimal (KKM) yang berlaku di SMA Islam Kota Ternate pada materi pokok ikatan kimia, seperti pada Tabel 2.

Tabel 2 Kriteria Ketuntasan Hasil Belajar Peserta Didik

\begin{tabular}{c|c}
\hline Interval Skor / Nilai & Kategori \\
\hline$\geq 70$ & Tuntas
\end{tabular}

\begin{tabular}{llr}
$<70$ & \multicolumn{2}{c}{ Tidak Tuntas } \\
\hline Sumber: SMA Islam Kota Ternate \\
Analisis & statistik & inferensial \\
digunakan untuk & menguji & kebenaran \\
hipotesis yang & diujikan. & Sebelum \\
melakukan analisis & statistik inferensial, \\
maka sebagai uji prasyarat dilakukan uji \\
normalitas dan uji homogenitas dengan \\
menggunakan program aplikasi statistika
\end{tabular}

SPSS. Jika uji prasyarat memenuhi criteria normal dan homogen maka digunakan statistika parametrik untuk analisis statistik inferensial, sebaliknya jika kriteria normal dan homogeni tidak terpenuhi maka digunakan statistika nonparametrik.

Uji normalitas digunakan untuk mengetahui apakah data yang diteliti berasal dari populsi yang terdistribusi normal. Pengujian normalitas data hasil belajar peserta didik dihitung menggunakan bantuan SPSS 24 dengan analisis onesample-kolmo. Criteria gorov-smirnov test. Kriteria pengujian: apabila signifikan (p) yang diperoleh lebih besar dari $\alpha=0.05$ maka data tersebut berasal dari populasi yang terdistribusi normal dan sebaliknya.

Asumsi normalitas merupakan prasyarat kebanyakan prosedur statistika inferensial. Pada penelitian ini asumsi normalitas dieksplorasi menggunakan uji normalitas Lilliefors (Klomogorov smirnov) melalui SPSS dengan taraf signifikansi $\alpha=$ 0.05 . bentuk hipotesis untuk uji normalitas adalah:

H0 : angka signifikan (sig) $>0.05$ maka data berditribusi normal

H1 : angka signifikan (sig) $<0.05$ maka data tidak berditribusi normal

Uji homogenitas digunakan untuk mengetahui apakah kedua sampel yang diambil berasal dari populasi yang homogen (mempunyai varians yang sama). Pengujian homogenitas dihitung dengan bantuan program SPSS menggunakan analisis Levene's Test of Equality of error Variance. dengan kriteria pengujian: jika signifikansi (p) yang diperoleh lebih besar dari $\alpha=0.05$ maka data tersebut homogen. 
Uji homogenitas digunakan untuk mengetahui distribusi data, apakah homogen atau tidak homogen. Uji homogenitas dilakukan dengan cara membandingkan varian tersebar dan varian terkecil dengan menggunakan tabel. (Santoso, 2008).

Sementara akdon (2008) merincikan langkah-langkah uji homogenitas sebagai berikut:

Mencari nilai varian terbesar dan terkecil kemudian mencari $\mathrm{F}$ hitung dengan rumus:

$$
\text { Nilai }=\frac{\text { Varian besar }}{\text { Varian kecil }}
$$

Membandingkan nilai Fhitung dengan Ftabel dengan kriteria; jika Fhitung $<$ Ftabel, maka varians adalah homogen dan uji komparatif dapat dilakukan.

Uji hipotesis. Dalam pengujian hipotesis, kriteria untuk menolak atau tidak menolak H0 berdasarkan P-value adalah jika $\mathrm{P}$-value $<\alpha$ maka $\mathrm{H} 0$ ditolak dan jika $\mathrm{P}$-value $\geq \alpha$ maka H0 tidak dapat ditolak. Dalam program SPSS 21 digunakan istilah significance yang disingkat Sig untuk Pvalue, dengan kata lain P-value $=$ Sig .

\section{HASIL DAN PEMBAHASAN}

Hasil penelitian yang disajikan meliputi uji hipotesis, deskripsi hasil belajar dan deskripsi kesadaran metakognisi.

\section{Pengujian Analisis Prasyarat}

Sebelum melakukan analisis statistik inferensial, maka sebagai uji prasyarat analisis dilakukan uji normalitas dan uji homogenitas dengan bantuan SPSS 21. Jika uji prasyarat memenuhi kriteria normal dan homogen maka digunakan statistik parametrik, sebaliknya jika kriteria normal dan homogen tidak terpenuhi maka digunakan statistik non parametrik.

Uji normalitas digunakan untuk mengetahui apakah data yang diteliti berasal dari populasi yang berdistribusi normal. Dengan kriteria pengujian: jika signifikansi (p) $>(\alpha)$ berarti H1 ditolak dan H0 diterima, maka data tersebut berdistribusi normal sebaliknya jika signifikansi $(p)<(\alpha)$ berarti
H1 diterima dan H0 ditolak, maka data tersebut tidak berdistribusi normal. Pengujian normalitas dihitung dengan bantuan program SPSS 21 dan menggunakan analisis one-sampleklomogrov-smirnov test. Bentuk hipotesis untuk uji normalitas adalah sebagai berikut:

H0 : angka signifikan (sig) > 0,05 maka data berdistribusi normal

H1 : angka signifikan (sig) $<0,05$ maka data tidak berdistribusi normal

Uji normalitas menunjukkan peserta didik dalam populasi tersebut berada dalam kategori memiliki pengetahuan yang sama secara keseluruhan atau tidak. Jika tidak terdistribusi normal dapat diartikan bahwa hampir semua peserta didik dalam populasi tersebut tingkat pengetahuannya sama, sebaliknya jika terdistribusi normal dapat diartikan bahwa setiap peserta didik dalm populasi tersebut memiliki tingkatan pengetahuan yang berbeda-beda. Kelas pada model pembelajaran inkuiri terbimbing nilai sig $0,145>0,05$ berarti H0 diterima begitupun pada model pembelajaran berbasis masalah nilai sig $0,200>0,05$ berarti $\mathrm{H} 0$ diterima maka dapat disimpulkan bahwa hasil belajar pada kelas dengan kedua model pembelajaran tesebut berdistribusi normal, selengkapnya dapat dilihat pada Tabel 3 .

Tabel 3 hasil analisis normalitas nilai hasil belajar peserta didik yang dengan model pembelajaran inkuiri terbimbing dan berbasis masalah

\begin{tabular}{c|lc|c|c}
\hline \multirow{2}{*}{$\begin{array}{c}\text { Model } \\
\text { pembelajaran }\end{array}$} & \multicolumn{3}{c}{$\begin{array}{c}\text { Kolmogorov- } \\
\text { smirnov }\end{array}$} \\
\cline { 3 - 5 } \multicolumn{2}{c}{$\begin{array}{l}\text { Statisti } \\
\text { c }\end{array}$} & Df & Sig. \\
\hline Hasil & $\begin{array}{l}\text { Inkuiri } \\
\text { Belajar }\end{array}$ & .137 & 31 & .145 \\
& $\begin{array}{l}\text { terbimbin } \\
\text { g }\end{array}$ & .107 & 30 & .200 \\
\hline
\end{tabular}

Uji homogenitas digunakan untuk mengetahui apakah kedua sampel yang diambil berasal dari populasi yang homogen. Dengan kriteria pengujian: jika 
signifikansi $(p)>(\alpha)$ berarti H0 diterima, maka data tersebut homogen sebaliknya jika signifikansi $(\mathrm{p})<(\alpha)$ berarti $\mathrm{H} 1$ diterima, maka data tidak homogen. Pengujian homogenitas dihitung dengan bantuan SPSS 21 menggunakan analisis Levene's test of equality of error variance.

Hasil penelitian homogenitas menunjukkan bahwa nilai sig 0,090>0,05 artinya H0 diterima. Sehingga dapat disimpulkan bahwa nilai hasil belajar peserta didik berasal dari populasi yang homogen, selengkapnya dapat dilihat pada Tabel 4.

\begin{tabular}{lcccc}
\hline & $\begin{array}{c}\text { Levene } \\
\text { Statistic }\end{array}$ & df1 & df2 & Sig. \\
\cline { 2 - 5 } Hasil & 2.273 & 3 & 57 & .090 \\
Belajar & & & & \\
\hline
\end{tabular}

\section{Pengujian hipotesis}

Uji prasyarat telah dilakukan dan diperoleh data yang berdistribusi normal dengan populasi yang homogen, maka dilanjutkan dengan uji hipotesis. Hasil pengujian hipotesis merupakan jawaban dari rumusan masalah yang telah dibuat dan Pengujian hipotesis dengan menggunakan analisis anova. Adapun hasil pengujian hipotesis dapat dlihat pada Tabel 5.

Tabel 5 Hasil Analisis Anova

\begin{tabular}{l|c}
\hline \multicolumn{1}{c|}{ Sumber } & Sign. \\
\hline Model Pembelajaran & 0,001 \\
Kesadaran Metakognitif & 0,008 \\
Model & 0,014 \\
Pembelajaran*Kesadaran & \\
\hline
\end{tabular}

\section{1) Hipotesis I}

Hasil analisis menunjukkan bahwa nilai sig, $0.001<\alpha=0,05$ berarti H0 ditolak dan $\mathrm{H} 1$ diterima artinya terdapat perbedaan hasil belajar peserta didik kelas XI IPA SMA Islam Kota Ternate yang menggunakan model pembelajarn inkuiri terbimbing dan model pembelajaran berbasis masalah pada materi ikatan kimia

\section{2) Hipotesis II}

Hasil analisis menunjukkan bahwa nilai sig, $0,008<\alpha=0,05$ berarti H0 ditolak dan $\mathrm{H} 1$ diterima artinya terdapat perbedaan hasil belajar peserta didik kelas XI IPA SMA Islam Kota Ternate yang menggunakan model pembelajarn inkuiri terbimbing dan model pembelajaran berbasis masalah pada materi ikatan kimia.

\section{3) Hipotesis III}

Hasil analisis menunjukkan bahwa nilai sig, $0.014<\alpha=0,005$ berarti H0 ditolak dan $\mathrm{H} 1$ diterima artinya terdapat perbedaan antara hasil belajar peserta didik pada kesadaran metakognisi yang menggunakan model pembelajaran inkuiri terbimbing dengan hasil belajar peserta didik pada kesadaran metakognisi yang menggunakan model pembelajaran berbasis masalah. oleh karena itu adanya perbedaan maka dapat disimpulkan bahwa diperoleh interaksi antara model pembelajaran dengan kesadaran metakognisi dalam mempengaruhi hasil belajar peserta didik. Hipotesis ketiga juga dapat dilihat pada grafik seperti Gambar 1.

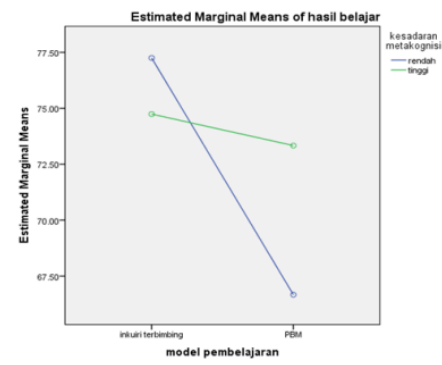

Gambar 1 Interaksi Antara Model Pembelajaran Dengan Kesadaran Metakognisi Peserta Didik Kelas X IPA Islam Kota Ternate

Ada atau tidak adanya interaksi antara model pembelajaran dan kesadaran metakognisi ditunjukkan oleh grafik pada Gambar 4.1 dan interaksi terjadi jika ada perpotongan garis antara model pembelajaran inkuiri terbimbing dengan model pembelajaran berbasis masalah sebaliknya jika tidak terjadi interaksi jika tidak ada perpotongan garis. Pada Gambar grafik diatas terdapat perpotongan garis 
maka dapat disimpulkan bahwa ada interaksi antara model pembelajaran dengan kesadaran metakognisi dalam mempengaruhi hasil belajar peserta didik kelas X IPA SMA Islam Kota Ternate pada materi ikatan kimia.

\section{Deskripsi Kesadaran Metakognisi dan Model Pembelajaran}

Hasil analisis deskripsi hasil belajar ditinjau dari kesadaran metakognisi peserta didik kelas X IPA SMA Islam Kota Ternate disajikan pada Tabel 6 .

Tabel 6 Deskripsi hasil belajar kesadaran metakognitif tinggi dan rendah peserta didik kelas X IPA SMA Islam Kota

\begin{tabular}{ccccc}
\hline \multirow{2}{*}{ Statistik } & \multicolumn{3}{c}{ Kesadaran metakognisi } \\
\cline { 2 - 5 } & Inkuiri terbimbing & \multicolumn{2}{c}{ PBM } \\
\cline { 2 - 5 } & Tinggi & Rendah & Tinggi & Rendah \\
\hline $\mathrm{N}$ & 24 & 7 & 8 & 22 \\
Mean & 77,62 & 68,71 & 76,62 & 69,18 \\
Median & 76,40 & 70,00 & 76,00 & 70,12 \\
Varians & 19,46 & 12,90 & 18,55 & 7,68 \\
Std. & 4,41 & 3,51 & 4,30 & 2,77 \\
deviasi & & & & \\
Range & 19,00 & 8,00 & 13,00 & 11,00 \\
\hline
\end{tabular}

Tabel 6 mendeskripsikan hasil belajar peserta didik yang memiliki kesadaran metakognisi tinggi dan kesadaran metakognisi rendah. Pada Tabel 6 terlihat bahwa kesadaran metakognisi tinggi lebih banyak berada pada model pembelajaran inkuiri terbimbing dibandingkan pada model pembelajaran berbasis masalah.

Hasil analisis deskripsi hasil belajar ditinjau dari model pembelajaran peserta didik kelas X IPA SMA Islam Kota Ternate untuk kedua kelas yang dibelajarkan dengan model pembelajaran inkuiri terbimbing dan pembelajaran berbasis masalah terlihat pada Tabel 7.

Tabel 7 deskripsi hasil belajar peserta didik yang dibelajarkan dengan model pembelajaran inkuiri terbimbing dan model pembelajaran berbasis masalah dengan kesadaran metakognitif tinggi dan rendah

\begin{tabular}{ccc}
\hline \multirow{3}{*}{ Statistik } & \multicolumn{2}{c}{ Nilai Hasil Belajar } \\
& Kelas Inkuiri & Kelas PBM \\
Terbimbing & \\
\hline $\mathrm{N}$ & 31 & 30 \\
Mean & 74,93 & 66,76 \\
Median & 77,00 & 70,00 \\
Varians & 158,99 & 60,53 \\
Std. deviasi & 12,60 & 7,78 \\
Range & 67,00 & 32,00 \\
\hline
\end{tabular}

Tabel 7 mendeskripsikan hasil belajar peserta didik pada kelas yang dibelajarkan menggunakan model pembelajaran inkuiri terbimbing dan model pembelajaran berbasis masalah. Pada Tabel terlihat bahwa nilai rata-rata hasil belajar untuk kelas yang dibelajarkan menggunakan model pembelajaran inkuiri terbimbing lebih tinggi yaitu 74,93 dibandingkan dengan kelas yang dibelajarkan menggunakan model pembelajaran berbasis masalah yaitu 66,76 .

Nilai rata-rata dikelompokkan dalam dua kategori menurut kriteria ketuntasan yang digunakan di SMA Islam Kota Ternate sehingga diperoleh distribusi ketuntasan hasil belajar seperti yang terlihat pada Tabel 8.

Tabel 8 Distribusi Frekuensi dan Ketuntasan Hasil Belajar Peserta Didik SMA Islam Kota Ternate

\begin{tabular}{|c|c|c|c|c|c|c|}
\hline \multirow{2}{*}{$\begin{array}{l}\mathrm{N} \\
\mathrm{O}\end{array}$} & \multirow{2}{*}{$\begin{array}{c}\text { Kateg } \\
\text { ori }\end{array}$} & \multirow{2}{*}{$\begin{array}{l}\mathrm{K} \\
\mathrm{K} \\
\mathrm{M}\end{array}$} & \multicolumn{2}{|c|}{$\begin{array}{c}\text { Inkuiri } \\
\text { Terbimbing }\end{array}$} & \multicolumn{2}{|c|}{ PBM } \\
\hline & & & $\begin{array}{c}\text { Freku } \\
\text { ensi }\end{array}$ & $\begin{array}{c}\text { Persen } \\
\text { tase }\end{array}$ & $\begin{array}{c}\text { Freku } \\
\text { ensi }\end{array}$ & $\begin{array}{c}\text { Persen } \\
\text { tase }\end{array}$ \\
\hline 1 & $\begin{array}{c}\text { Tunta } \\
\text { S }\end{array}$ & $\begin{array}{c}\geq 7 \\
0\end{array}$ & 26 & 83,9 & 16 & 53,3 \\
\hline 2 & $\begin{array}{l}\text { Tidak } \\
\text { tuntas }\end{array}$ & $\begin{array}{c}<7 \\
0\end{array}$ & 5 & 16,1 & 14 & 46,7 \\
\hline & $\begin{array}{c}\text { Jumla } \\
\mathrm{h}\end{array}$ & & 31 & 100 & 30 & 100 \\
\hline
\end{tabular}

Pada Tabel 8 Menunjukkan distribusi frekuensi dan kategori ketuntasan hasil belajar peserta didik terlihat bahwa pada kelas yang dibelajarkan menggunakan model pembelajaran inkuiri terbimbing memiliki ketuntasan hasil belajar terhadap peserta didik lebih tinggi dibandingkan dengan model pembelajaran berbasis masalah. Peserta didik yang tuntas adalah 26 orang $(83,9 \%)$, sedangkan yang tidak 
tuntas adalah 5 orang $(16,1 \%)$. Pada kelas yang dibelajarkan menggunakan model pembelajaran berbasis masalah, persentase ketuntasan peserta didik adalah 16 orang $(53,3 \%)$ dan yang tidak tuntas adalah 14 orang $(46,7 \%)$.

Penelitian ini bertujuan untuk mengetahui pengaruh model pembelajaran dan kesadaran metakognisi terhadap hasil belajar peserta didik kelas X IPA SMA Islam Kota Ternate pada pokok bahasan ikatan kimia. Berdasarkan pada rumusan masalah bahwa pengaruh perlakuan terhadap hasil belajar secara operasional dapat dilihat perbedaan hasil belajar peserta didik dari kelompok yang dibandingkan. Sehingga dalam pembahasan ini perbedaanperbedaan tersebut akan dikembalikan ke pengertian pengaruh. Hal ini dapat disimpulkan bahwa jika ada perbedaan maka ada pengaruh.

Berdasarkan uraian diatas penelitian ini lebih menekankan pada penilaian ranah kognitif, hal ini karena pada materi ikatan kimia berkaitan dengan banyak konsep sehingga pada penelitian ini lebih difokuskan pada ranah kognitif. Dimana pada ranah kognitif lebih mengutamakan kemampuan menghafal, rnemahami, mengaplikasi, menganalisis, mensintesis dan kemampuan mengevaluasi. Hal ini karena peneliti lebih mengutamakan tingkat intelektual berpikir peserta didik dalam merumuskan masalah, mencari informasi dan mengevaluasi materi dalam proses pembelajaran untuk mencapai hasil belajar yang baik.

\section{Pengaruh model pembelajaran terhadap hasil belajar peserta didik kelas X SMA Islam Kota Ternate}

Berdasarkan hasil analisis statistik deskripsi diperoleh nilai rata-rata peserta didik yang dibelajarkan menggunakan model pembelajaran inkuiri terbimbing lebih tinggi dibandingkan dengan dibelajarkan menggunakan model pembelajaran berbasis masalah. Hal ini menunjukkan bahwa model pembelajaran inkuiri terbimbing lebih baik jika dibandingkan dengan model pembelajaran berbasis masalah.

Hasil analisis inferensial diperoleh nilai signifikan $0,01<0,05$. Sehingga dapat disimpulkan bahwa ada perbedaan hasil belajar antara peserta didik yang dibelajarkan menggunakan model pembelajaran inkuiri terbimbing dengan peserta didik yang dibelajarkan menggunakan model pembelajaran berbasis masalah pada pokok bahasan ikatan kimia di kelas X IPA SMA Islam Kota Ternate. Adanya perbedaan terhadap hasil belajar peserta didik berarti adanya pengaruh atau dapat dikatakan bahwa ada pengaruh model pembelajaran terhadap hasil belajar peserta didik.

Hasil analisis data penelitian tentang hasil belajar peserta didik pada setiap kelas eksperimen menunjukkan bahwa hasil belajar peserta didik yang dibelajarkan dengan model pembelajaran inkuiri terbimbing lebih tinggi dibandingkan dengan nilai peserta didik yang dibelajarkan menggunakan model pembelajaran berbasis masalah. Berdasarkan pada ketuntasan hasil belajar, rata-rata nilai hasil belajar peserta didik yang dibelajarkan menggunakan model pembelajaran inkuiri terbimbing memiliki ketuntasan lebih banyak dibandingkan ketuntasan hasil belajar peserta didik yang diajar dengan menggunakan model pembelajaran berbasis masalah. Hal seperti ini dapat terjadi karena karakteristik peserta didik cukup berbeda pada kedua kelas eksperimen. Selanjutnya, diketahui bahwa karakteristik pengetahuan yang dimiliki peserta didik yang dibelajarkan dengan model inkuiri terbimbing lebih baik dibandingkan dengan peserta didik yang dibelajarkan dengan model PBM.

Banyaknya peserta didik yang mencapai kategori tuntas disebabkan karena peserta didik aktif selama proses pembelajaran. Selama proses pembelajaran peserta didik berkesempatan untuk mencari 
dan menemukan konsep-konsep baru yang dipelajari. Selain itu pada model pembelajaran, peserta didik juga dapat melatih diri secara mandiri dalam proses pembelajaran untuk menelaah literatur dan mencari informasi sehingga peserta didik dapat memperoleh informasi yang lebih banyak yang dapat membantu peserta didik dalam proses pembelajaran berlangsung. Adapun faktor lain yang menyebabkan peserta didik mencapai kategori tuntas yaitu berdasarkan indikator tes hasil belajar yang yang hanya meliputi aspek $\mathrm{C} 1$ (pengetahuan), C2 (pemahaman) dan $\mathrm{C} 3$ (penerapan) sehingga peserta didik mudah dalam menjawab soal tes hasil belajar. Berdasarkan faktor tersebut dapat disimpulkan bahwa hasil belajar kognitif merupakan kemampuan intelektual yang dimiliki oleh peserta didik dari pengalaman belajar dalam mengkonstruk secara mandiri melalui pemahaman dan proses pikiran dengan mengasimilasi dan mengakomodasi informasi baru setelah berinteraksi dengan lingkungan dalam proses pembelajaran.

Model pembelajaran inkuiri terbimbing memberikan hasil belajar yang lebih tinggi dari model pembelajaran berbasis masalah. Khususnya pada pokok bahasan ikatan kimia. Hal ini terjadi karena pada model pembelajaran inkuiri terbimbing mampu memperbaiki dan meningkatkan keterampilan-keterampilan dalam proses belajar peserta didik misalnya usaha inkuiri terbimbing yang dilakukan tergantung pada bagaimana cara belajar peserta didik tersebut oleh karena itu, pengetahuan yang ditemukan dalam hal ini bersifat sangat pribadi dan ampuh hingga mampu menguatkan pengertian, ingatan dan transfer yang baik. Hal ini merupakan suatu kesenangan tersendiri karena peserta didik berhasil dan percaya dalam menemukan suatu konsep dan prinsip karena mampu bekerja sama dengan yang lainnya dalam satu kelompok. Model ini mampu membuat peserta didik berkembang dengan dan menemukan sendiri informasi dan konsep- konsep baru serta melakukan penyelidikan terhadap suatu masalah dan dapat memperoleh pengetahuan yang lebih bermakna. Hal ini sejalan dengan penelitian yang dilakukan oleh (Sumarni dkk, 2017) bahwa model pembelajaran inkuiri terbimbing berpengaruh terhadap hasil belajar kimia di SMA Negeri 1 Manokwari pada pokok bahasan kelarutan dan hasil kali kelarutan.

Adapun kendala atau kelemahan dari model pembelajaran inkuiri terbimbing dan PBM yaitu keterbatasan waktu, sedangkan model pembelajaran ini memerlukan waktu yang banyak, sehingga diharapkan guru dalam melaksanakan proses belajar mengajar dapat merencanakan dan mengolah alokasi waktu dengan baik dan benar. Hal ini juga dapat diatasi melalui kegiatan pembelajaran yang melibatkan media penyampaian materi seperti LKPD dan menyuruh peserta didik untuk mencari dan mempelajari materi selanjutnya sehingga waktu yang diperlukan dalam proses belajar pembelajaran tidak terlalu lama.

\section{Pengaruh kesadaran metakognisi terhadap hasil belajar peserta didik kelas X SMA Islam Kota Ternate}

Berdasarkan hasil analisis inferensial memperlihatkan bahwa signifikansi yang diperoleh $0,008<0,05$ yaitu ada perbedaan hasil belajar peserta didik yang memiliki kesadaran metakognisi tinggi dan kesadaran metakognisi rendah pada materi pokok ikatan kimia kelas X IPA SMA Islam Kota Ternate.

Berdasarkan data hasil belajar yang diperoleh bahwa peserta didik yang memiliki kesadaran metakognisi tinggi lebih besar dibandingkan peserta didik yang memiliki kesadaran metakognisi rendah. Hal ini terjadi karena peserta didik dengan kesadaran metakognisi tinggi mampu merancang apa yang hendak dipelajari dan menilai apa yang telah dipelajari. Selain itu peserta didik dengan kesadaran metakognisi tinggi mampu untuk mengontrol, memantau 
dan mengendalikan diri dalam pembelajarannya. Hal ini sejalan dengan penelitian yang dilakukan oleh (Bahri, 2010) yang mengatakan bahwa peserta didik yang memiliki kesadaran metakognisi tinggi akan memberikan dampak yang baik juga terhadap hasil belajar kognitifnya.

Hasil penelitian menunjukkan bahwa kesadaran metakognisi memiliki pengaruh terhadap hasil belajar peserta didik. Semakin sering siswa sadar tentang proses berpikirnya saat belajar, maka semakin mereka mampu mengontrol hal-hal seperti tujuan, motivasi dan perhatian. Hasil belajar peserta didik yang memiliki tingkat metakognisi tinggi akan lebih baik jika dibandingkan siswa yang memiliki tingkat metakognisi rendah. Siswa yang memiliki prestasi akademik yang rendah dapat diperbaiki melalui latihan metakognisi. Hal ini sejalan dengan penelitian yang dilakukan oleh (Maryam R, 2013) bahwa kesadaran metakognisi berpengaruh terhadap hasil belajar kognitif peserta didik kelas XI IPA SMA Negeri 1 Sigeri pokok bahasan larutan penyangga.

Peserta didik yang memiliki kesadaran metakognisi yang baik mampu menggunakan proses berpikir dalam berpikir lancar, berpikir luwes, berpikir orisinal dan berpikir elaboratif sehingga dapat mempengaruhi hasil belajar. Adanya perbedaan hasil belajar pada kesadaran metakognisi disebabkan oleh karakteristik dasar peserta didik sehingga lahirlah peserta didik dengan kesadaran metakognisi tinggi dan kesadaran metakognisi rendah yang nantinya akan memberikan pengaruh pada hasil belajar. Oleh karena itu akan diperoleh peserta didik yang mampu memiliki hasil belajar yang baik maupun yang kurang baik sehingga mampu mempengaruhi ketuntasan hasil belajar peserta didik kearah yang lebih baik pada kelas yang dibelajarkan dengan model inkuiri terbimbing dan PBM di SMA Islam Kota Ternate pada materi ikatan kimia. Dikatahui bahwa dengan kesadaran metakognisi tinggi mampu mempengaruhi hasil belajar peserta didik kearah yang lebih baik dibandingkan kesadaran metakognisi rendah. Selain perbedaan ketuntasan hasil belajar yang diperoleh disebabkan karakteristik peserta didik yang berbeda pada kelas yang dibelajarkan dengan model inkuiri terbimbing dan PBM. Meskipun ketuntasan hasil belajar yang diperoleh berbeda. Namun hasil belajar yang diperoleh cukup mengalami perubahan kearah yang lebih baik dari sebelumnya.

Kesadaran metakognisi merupakan kesadaran berpikir seseorang tentang berpikirnya sendiri. Peserta didik yang menggunakan kesadaran metakognisi dalam pembelajarannya dapat merancang apa yang hendak dipelajari, memantau perkembangan diri dalam belajar dan menilai apa yang dipelajari, sehingga peserta didik secara sadar mengontrol proses berpikir dalam pembelajaran yang dilakukan. Dengan menerapkan kesadaran metakognisi maka peserta didik akan mampu mengontrol kelemahan diri dalam belajar dan kemudian akan memperbaiki kelemahan tersebut, dapat menentukan cara belajar yang tepat sesuai dengan kemampuannya sendiri, dapat menyelesaikan masalah-masalah dalam belajar baik yang berkaitan dengan soal-soal yang diberikan oleh guru dan dapat memahami sejauh mana keberhasilan yang telah dicapai dalam belajar. Kesadaran metakognisi memilki peranan penting dalam menyelesaikan masalah. khususnya dalam mengatur dan mengontrol aktifitas kognitf peserta didalam menyelesaikan masalah menjadi lebih efektif dan efesien. Hal ini berarti peserta didik yang memiliki kesadaran metakognisi tinggi akan memiliki kesadaran belajar yang tinggi sehingga akan memperoleh hasil belajar yang lebih baik. Hal ini sejalan dengan penelitian yang dilakukan oleh Maryam R (2013) bahwa kesadaran metakognisi pengaruh terhadap hasil belajar kognitif peserta didik kelas XI IPA SMA Negeri 1 rantepao pada materi pokok larutan penyangga. 
Adanya kesadaran metakognisi dalam pembelajaran memberikan petunjuk bahwa sudah sebaiknya proses pembelajaran yang dilakukan disekolah tidak hanya menekankan pada perkembangan kognitif saja, tetapi juga aspek metakognisinya sehingga proses pembelajaran bisa lebih baik lagi.

\section{Interaksi model pembelajaran dengan kesadaran metakognisi terhadap hasil belajar peserta didik kelas X SMA Islam Kota Ternate}

Hasil analisis penelitian menunjukkan bahwa pada kelas yang dibelajarkan dengan model pembelajaran inkuiri terbimbing yang memiliki nilai hasil belajar tinggi adalah peserta didik yang memiliki kesadaran metakognisi tinggi sedangkan peserta didik yang dibelajarkan menggunakan model pembelajaran berbasis masalah yang memiliki nilai hasil belajar rendah adalah peserta didik yang memiliki kesadaran metakognisi rendah.

Berdasarkan hasil analisis inferensial antara model pembelajaran dengan kesadaran metakognisi diperoleh nilai signifikan $0,014<0,05$ yaitu menunjukkan adanya perbedaan hasil belajar pada model pembelajaran dan kesadaran metakognisi peserta didik kelas X IPA SMA Islam Kota Ternate. Hal ini menunjukkan bahwa ada interaksi antara model pembelajaran dengan kesadaran metakognisi dalam mempengaruhi hasil belajar. Dapat juga dikatakan bahwa model pembelajaran yang digunakan dapat mempengaruhi kesadaran metakognisi.

Pada Gambar 4.3 menunjukkan bahwa peserta didik dengan kesadaran metakognisi tinggi memiliki hasil belajar yang lebih tinggi dibanding dengan peserta didik yang memiliki kesadaran metakognisi rendah untuk masing-masing model pembelajaran yang digunakan. Kedua garis terlihat saling berpotongan sehingga dapat disimpulkan bahwa ada interaksi antara model pembelajaran yang digunakan dengan kesadaran metakognisi dalam mempengaruhi hasil belajar.

Data penelitian mnunjukkan bahwa Peserta didik yang mempunyai kesadaran metakognisi tinggi dan kesadaran metakognisi rendah akan lebih baik jika dibelajarkan menggunakan model pembelajaran inkuiri terbimbing dibanding dengan menggunakan model pembelajaran berbasis masalah. Hal ini terlihat jelas pada Gambar 4.1 yang menunjukkan bahwa kesadaran metakognisi tinggi maupun rendah pada model pembelajaran inkuiri terbimbing jauh lebih tinggi dibandingkan pada model pembelajaran berbasis masalah.

Hal ini menunjukkan bahwa model pembelajaran inkuiri terbimbing baik digunakan untuk peserta didik yang memiliki tingkat kesadaran metakognisi yang tinggi maupun kesadaran metakognisi rendah. Inkuiri terbimbing merupakan model pembelajaran yang menekankan pada pengembangan keterampilan berpikir peserta didik melalui proses penyelidikan dan penemuan secara mandiri. Menurut Gulo dalam (Trianto, 2010) bahwa inkuiri merupakan rangkaian kegiatan belajar yang melibatkan kemampuan siswa untuk mencari dan menyelediki secara sistematis sehingga peserta didik dapat merumuskan sendiri penemuannya. Hal ini sejalan dengan teori belajar konstruktivisme yang salah satu prinsip dari teori belajar ini adalah bahwa peserta didik tidak boleh hanya menerima begitu saja informasi, pengetahuan ataupun materi namun peserta didik juga harus mampu menemukan dan membangun pengetahuan mereka sendiri. Dibantu oleh kesadaran metakognisi yang baik mampu mengontrol, memantau dan mengendalikan diri peserta didik dalam proses pembelajaran.

Berdasarkan hal tersebut, dapat disimpulkan bahwa hasil belajar peserta didik yang dibelajarkan menggunakan model pembelajaran inkuiri terbimbing lebih baik dibandingkan dengan peserta didik yang dibelajarkan dengan model 
pembelajaran berbasis masalah serta hasil belajar peserta didik yang memiliki kesadaran metakognisi tinggi lebih baik dibandingkan dengan peserta didik yang memiliki kesadaran metakognisi rendah. Oleh karena itu terjadi interaksi antara model pembelajaran dengan kesadaran metakognisi dalam mempengaruhi hasil belajar peserta didik kelas X SMA Islam Kota Ternate pada meteri pokok ikatan kimia. Hal ini sejalan dengan penelitan yang dilakukan oleh (Tamsyani, 2015) bahwa ada pengruh model pembelajaran dan kesadaran metakognisi terhadap hasil belajar peserta didik kelas XI SMA Negeri 2 Takalar pada materi pokok asam basa.

\section{SIMPULAN}

Berdasarkan hasil analisis data penelitian dan pembahasan hasil penelitian, maka kesimpulan dari hasil penelitian ini adalah Model pembelajaran dan kesadaran metakognisi saling berinteraksi dalam mempengaruhi hasil belajar, jadi model pembelajaran dan kesadaran metakognisi berpengaruh terhadap hasil belajar peserta didik kelas $\mathrm{X}$ IPA SMA Islam Kota Ternate.

\section{DAFTAR RUJUKAN}

Akdon dan Riduwan. 2008. Aplikasi Statistika Dan Metode Penelitian Eksperimen nkuiri Terbimbing Berbantuan My Own Dictionary untuk Meningkatkan Penguasaan Konsep dan untuk Kerja Siswa SMP RSBI.Journal Education.1 (2).

Haryani. (2012). Membangun Metakognisi Dan Karakter Calon Guru Melalui Pembelajaran Praktikum Kimia Analitik Berbasis Masalah. Unnes Pres.

Linanti, A. T., Anwar, Y., \& Santoso, L. M. (2017). Pengaruh Penenrapan Model Pembelajaran Inkuiri Terbimbing (Guided Inquiry) Terhadap Ketrampilan Metakognitif Peserta Didik Kelas XI SMA Negeri 19
Untuk Administrasi Dan

Manajmen. Bandung: Dewi Ruci.

Amir, T. (2009). Inovasi Pendidikan Problem Based Learning: Bagaimana Pendidik Memberdayakan Pembelajar di Era Pengetahuan. Jakarta: Kencana Prenada Media.

Arikunto, Suharsimi. 2006. Prosedur Penelitian; Suatu Pendekatan Praktek. Jakarta. Rineka Cipta.

Bahri, A. 2010. Pengaruh Strategi Pembelajaran Reading Questioning and Answering (RQA) pada Perkuliahan Fisiologi Hewan Terhadap Kesadaran Metakognitif, Keterampilan Metakognitif dan Hasil Belajar Kognitif Mahasiswa Jurusan Biologi FMIPA Universitas Negeri Makasar. Tesis tidak diterbitkan.

Blackey, Elaine dan spance, Sheila. 2008. Developing Metacognition, (online),

http://www.literacy.Kent.edu/ohioe ff/resource.doc, Diakses 15 April 2018.

Ghajali, Imam. 2006. Statistika Nonparametrik. Semarang.: badan penerbit UNDIP

Handayani., L, Sarwi., Praptiwi, L. 2012. Efektivitas Model Pembelajaran Palembang Pada Materi Sistem Eksresi.

Maryam. R. 2013. Pengaruh Model Pembelajaran dan Kesadaran Metakognisi Terhadap Hasil Belajar Kognitif (studi pada mata pelajaran kimia kelas XI IPA SMA Negeri 1 Sigeri dan Negeri 1 Rantepao), Tesis Pendidikan Kimia. Universitas Negeri Makassar.

Santoso, Singgih. 2008. Statistik Non Parametrik. Jakarta: PT. Elex Media Komoutindo.

Sumarni, dkk (2017). Pengaruh Model Pembelajaran Inkuiri Terbimbing Terhadap Hasil Belajar Kognitif 
Peserta Didik di SMA Negeri 01 Manokwari (Studi Pada Pokok Bahasan Kelarutan Dan Hasil Kali Kelarutan). Jurnal Nalar Pendidikan, Vol 5, Hal 21-30.

Suryanti, R.D (2010). Strategi Pembelajaran Kimia. Yogyakarta : Graha ilmu

Tamsyani, W. (2016). Pengaruh Model Pembelajaran dan Kesadaran Metakognitif Terhadap Hasil Belajar Peserta Didik SMA Dalam Materi Pokok Asam Basa . Journal Of EST, Vol 2, Hal. 10-25.

Undang-Undang Republik Indonesia Nomor 20 Tahun 2003 Tentang Sistem Pendidikan Nasional . (2006). Jakarta: PT Arnas Duta Jaya.

Wibowo. (2007). Manajemen Kinerja. jakarta: PT Rajagrafindo Persada. 